\title{
Women's movements and the State in Portugal: a State feminism approach
}

Rosa Monteiro

\& Virgínia Ferreira*

Abstract: This paper aims to contribute towards a better understanding of the dynamics of women's movements and their relations with institutions, political parties and the official mechanisms used to promote gender equality. It is the outcome of the first study on State feminism in Portugal. Our research was carried out using a case study which focused on the main gender equality official mechanism and its networks, which required a qualitative approach. We concluded that currently, while the Portuguese State is confronted with its persistent inability to implement gender equality policies, the present situation of Portuguese women's movements is that of redefining and adjusting to the major challenge of reinvention and resignification within a very difficult external environment.

Keywords: women's movement, The State, State feminism, political parties, Portugal

\section{Introduction}

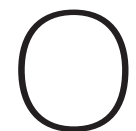

ver the past almost forty years of democracy, Portugal has eliminated sex discrimination from its legislation, taken on an international commitment to the gender equality agenda and policies for positive action and "gender mainstreaming" and created two permanent gender equality mechanisms. It possesses what is considered a favourable legal framework, the result of intensive legislative reform that took place between 1970 and 1980 in the wake of the new 1976 Constitution. These legislative accomplishments were extended the end of the 1990s, culminating in 1997 in a significant Constitutional ${ }^{1}$ upgrade and more recently, between 2005 and 2010, with the prolific legislative activity of the XVII and XVIII Constitutional Governments (Monteiro, 2011a). They represent legislative leaps forward which have, on the one hand, have created the necessary conditions for equality policies to be pursued, but, on the other, have challenged the State's capacity to ensure their effectiveness.

The remarkable legal framework nevertheless contrasts with the disjunction that exists between legal and political formalism and the de facto social situation. This has been cited as a salient and significantly disturbing feature of Portuguese society as far as gender equality is concerned, exposing the inability of the State and the weakness of Portuguese women's movements (Ferreira, 2011; Santos, 1993). This

\footnotetext{
* Rosa Monteiro é investigadora no Centro de Estudos Sociais (CES) da Universidade de Coimbra, professora auxiliar no Instituto Superior Miguel Torga. <monteiro. rosa14@gmail.com>. Virgínia Ferreira é professora auxiliar da Faculdade de Economia da Universidade de Coimbra e investigadora permanente do Centro de Estudos Sociais (CES, Coimbra, Portugal. <virginia@fe.uc.pt>.

1. The 1997

Constitution considered it a fundamental task of the State to promote gender equality and established the principle of non-discrimination on the basis of gender in access to political positions. It also enshrined the principle of legal protection against any kind of discrimination, the right to reconcile family and professional life and full maternity and paternity rights.
} 
2. Descriptive representation means introducing actors that speak for women and gender equality into the policy-making arenas. Substantive representation means bringing equality and women's issues into the discussion, formulation and implementation of policies (Mazur, 2005: 3).

3. It is well-known that this concept is controversial, especially when linked to the concept of representation (Celis, 2008). We agree with Celis that women's interests "are a priori undefined, context-related, and subject to evolution" (Celis, 2008: 78), and with her Statement that "representing women ('s interests) is to denounce a situation that is disadvantageous for women, to formulate a proposal to improve the situation of women or to claim a right for women with the same goal" (Celis, 2008: 92).

4. The definition proposed by McBride and Mazur (2008: 226) has been adopted, namely that "a women's movement means collective action by women organized explicitly as women presenting claims in public life based on gendered identities as women". This definition does not disjunction is not limited to results, reflected in the practices and representations of subjects and statistical data revealing persistent inequalities, but is overwhelmingly evident in the comparison between production and implementation of State policies addressing this social problem (Ferreira et alii, 2007b; 2011). It has been cited as a sign of the weakness of the legal utopia of the neoliberal State (Santos, 2005), and this ineffectiveness is a point of tension between the State and social movements that has endured in the country from the 1970s to the present day. Embodying the crisis in the legal utopia (Santos, 2005), it has served as a catalyst for reflections and analyses of the relation between the State and social movements and the processes involved in producing and implementing State equality policies (Ferreira, 2011; Monteiro, 2011a).

Reflecting on these contradictory political results, with their advances, retreats and ineffectiveness, involves questioning the extent and level to which democracy has really penetrated and created conditions for the descriptive and substantive representation ${ }^{2}$ of women's interests ${ }^{3}$. It also involves questioning the way in which democratization has incorporated Portuguese women's representatives and their demands, namely women's movements ${ }^{4}$ and the gender equality mechanisms ${ }^{5}$. What kind of conditions have restricted opportunities for these representatives in the years of democracy, determining their strategic options and ultimately contributing towards this disjunction? This text aims to answer these questions by analysing the relation between the State and women's movements in Portugal in the light of certain analytical proposals contained in the State feminism approach (Lovenduski, 2008; McBride \& Mazur, 1995; 2008; Mcbride, 2001).

This approach studies the nexus between gender equality mechanisms and women's movements in the production of political results, taking the former to be decisive agents in terms of links between the movements and the State (Lovenduski, 2008; McBride \& Mazur, 1995; 2008; McBride, 2001). Dorothy McBride and Amy Mazur define State feminism as the

\footnotetext{
actions by women's policy agencies to include women's movement demands and actors in the State to produce feminist outcomes in either policy process or societal impact or both (McBride \& Mazur, 2008: 255).
}

The approach assumes that the mechanisms facilitate both descriptive and substantive representation, setting themselves up as potential allies of women's movements in gaining access to political decision-making (Mazur \& McBride 2005; 2010). Inspired by political process theories (McAdam 1998; Tarrow 1998), it also assumes that it is the characteristics of the concrete socio-political context or 
system, namely the political opportunity structures, that influence the success of State feminism, rather than the characteristics of the mechanisms or the actual women's movements (Mazur \& McBride, 2010).

There has been little research into Portuguese gender equality policies and their actors (e.g. women's movements, gender equality mechanisms, and political parties). This paper aims to contribute towards a better understanding of the history of Portuguese society, approaching the process of democratization and the main social and political features of Portuguese society from a new perspective, whereby the focus of analysis is the dynamics of the women's movements and their relations with Portuguese institutions, political parties and the official mechanisms put in place to promote gender equality. It is the outcome of the first study on State feminism in Portugal. Our research was carried out using a case study which focused on the main gender equality mechanism - now called the Commission for Citizenship and Gender Equality (Comissão para a Cidadania e Igualdade de Género- $\mathrm{CIG}$ ) - and its networks, which required a qualitative approach. Fifty three semi-structured interviews were conducted (with officials and former officials of the Commission, former presidents and higher-ranking officials of the Commission, politicians of the line ministries, gender experts, leaders of women's associations and movements, and female politicians). An extensive documental analysis was also applied to a large corpus comprising archival material (meeting minutes and other documents), legislation, reports, publications and press articles. The empirical work was carried out between 2008 and 2009.

The first part of this study presents in greater detail the process by which the Portuguese gender equality mechanism and the networks of women's associations created around it were formed. It is followed by reflections on the process of the political institutionalization of women's movements in Portugal, seeking to understand this in the light of the political opportunity structures offered by the institutional environment. In the third section, we present the main factors which explain the role of State feminism and finally, an analysis of the main changes and challenges facing State feminism and women's movements in Portugal.

Throughout this article and wherever applicable, the Portuguese experience is cast in comparison with that of Spain and Brazil, countries with which Portugal shares a past marked by dictatorial regimes and a democratization process from the 1970s onwards. This comparison helps to highlight the particularities of the Portuguese case as regards identification of the obstacles facing the effectiveness of State feminism. Moreover, it adds to the vast literature on the role of women's movements in shaping State feminism. prescribe disruptive or unconventional tactics in the definition of a movement, avoiding the tendency to establish a boundary between activism outside and inside the State, or between alliances and autonomous relations.

5. We follow Mazur and McBride's definition (2010: 29) of a "women's policy agency" as an agency or governmental body formally established by government statute or decree; formally charged with furthering women's status and rights or promoting sex-based equality. However, we prefer to use the term "gender equality mechanism". 


\section{The rise of the main Portuguese gender equality mechanism and the network of women's associations}

6. On 25 April 1974 a military coup - known as the Carnation Revolution - ended the fascist dictatorship that persisted for half a century (from 1926 to 1974).

7. Defined by Walker as "the changing location of social movement actors from a position largely external to the State to one in which movement actors are either recognized members of the State, work in close relation to the State or assist the State in policy-making, or are directly funded by the State" (Walker, 2005: 13). He distinguishes this type of institutionalization from the organizational type (in which movements come to be dominated by concerns related to organization) and the cultural type.
In 1974, the year of the "Carnation Revolution", the official gender equality mechanism then being set up, carried out a survey of all the existing women's organizations. It identified only three women's associations, some women's sections attached to political parties, trade unions representing a predominantly female workforce, and civic associations. The survey revealed two features: on the one hand, the incipient nature of the women's movements, their weakness and fragmentation (Tavares, 2011) and, on the other hand, the willingness of the gender equality mechanism to engage with and take on the role of uniting and promoting militancy for the women's cause in Portugal.

At the time, an institutional arena was being created within the Portuguese State for gender equality issues, namely the principal gender equality mechanism. This was the predecessor to the current Commission for Citizenship and Gender Equality (CIG) (DL 164/2007). The Commission was the result of a series of reforms to the original Working Group for the Definition of a General National Policy for Women, created in 1970 under the dictatorship, which survived until the 1974 Revolution. It was established in 1975 by its president and then Minister for Social Affairs (Maria de Lourdes Pintasilgo), who named it the Commission for the Feminine Condition (Comissão da Condição Feminina) (CCF). Finally, in 1977, the first post-Revolution Constitutional Government, a socialist government, institutionalized it under DecLaw 485/77. In 1991, Decree-Law 166/91 restructured the Commission for the Feminine Condition and re-named it the Commission for Equality and Women's Rights (Comissão para a lgualdade e os Direitos das Mulheres) (CIDM), which survived until 2007. The Commission (as referred to hereafter) has been the official gender equality mechanism with the broadest mandate and longevity. Its creation and development has decisively influenced the scenario of equality policies and the activism of women's movements in Portugal. Contrary to what happened in Brazil (Rangel, 2012), the Commission was not created following demands by the women's movements.

Certain women's networks have also been formed around the Commission. In fact, since the 1970s, the Commission has had an advisory body - the Advisory Council - which still has two sections. This has been an important point of contact for all government sectors and departments, in the case of the Interministerial Section, and for civil society organizations in the case of the Non-Governmental Organizations (NGO) Section. It has therefore been an important arena for political institutionalization ${ }^{7}$ (Walker, 2005) and for forging links with the fragile women's movements and women's sections of the political parties, which had little power. 
Over time, an increasing and very heterogeneous number of associations were included in the Section (in 1974-75 there were 12 and in 2007, 54). From 1991, the organizations which belonged to it were entitled to a subsidy for projects, included in the State budget as part of the Commission's budget and, until 2005-6, they were collectively entitled to the use of a room at the Commission head office where they could meet and work together.

These were early signs of a "move towards the State" and of favouring the common State platform as a mobilizing structure ${ }^{8}$ for the Portuguese women's movements, which has only undergone significant changes in recent times, as will be seen later. These features shaped a cooperative relation which surprised Célia Valiente, for example (1998), since it was very different from the antagonistic relation that characterized relations between women's associations and the Instituto de la Mujer in Spain. In fact, in Portugal the Commission, although not institutionalized, predated the actual women's movements, banned under the dictatorship, meaning that it had not been created as a result of demands on the part of civil society, as had been the case in other countries (McBride \& Mazur, 1995). The Statization and centralization involved in the creation of policies and feminist action, together with the prevalence of a liberal form of institutional feminism in Portugal, has been viewed critically by those who associate it with the suppression of autonomous action by feminist movements - the lack of more campaigning repertoires (Tavares, 2011) - and also the reduced effectiveness of policies (Ferreira, 1998). But how and why did this early political institutionalization of Portuguese women's movements come about? The answer is to be found in the closed political opportunity structures available within the context of the transition to democracy.

\section{The institutionalization of}

\section{women's movements and State feminism}

After more than four decades of obstacles and "dark times" (Pimentel, 2001; Tavares, 2011), with the revolution that began in April 1974 Portuguese women were able to benefit from the structural conditions that enabled them to organize and mobilise collectively. And they did so - but not in the way that would have been expected within a context of change and openness to democracy. The fact is that, as in other countries, the transition to democracy does not offer equal opportunities for political action for all types of movements and campaigns (Franceschet, 2003). The introduction of agendas other than those of the revolution is difficult, marked by resistance and even rejection, particularly if, under the illusion of modernization, there lie structures from the past and conservative institutional legacies (Htun \& Weldon, 2007; Valiente, 2005), as was the case in the Portuguese political system and society (Nicholls, 2007; Portugal, 2000; Santos, 1993).
8. According to Tarrow, this refers to the range of social actors (individual or collective, formal or informal) and entities involved in movements or in mobilizing around a particular agenda (1998). 
In Portugal, after women had been heavily involved in the revolutionary movements, it seemed there was no place for founding and establishing the visibility of autonomous feminist movements (Ferreira, 2011; Tavares, 2011), contrary to what happened in Brazil where women's movements saw $80 \%$ of their demands incorporated into the 1988 Constitution (Avelar, 2013). Manuela Tavares refers to this lack of campaigning by and on behalf of women, citing the significant comment of one feminist during the revolution:

There are so many women here and they aren't even demanding their rights! [...] we still don't have rights, not even over our own children, and we are not calling for these rights in demonstrations (Tavares, 2011: 254).

Substantive representation of women's interests was suppressed in political decision-making spheres. This was evident in the unsuccessful appeals made by the Armed Forces Movement Commission for Women's Affairs to the Constitutional Assembly and the political parties to include women's issues in the revolutionary agenda, and also the non-receptiveness of the Constitutional Assembly to the proposals and involvement of Portuguese women's representatives in producing the 1976 Constitution (Monteiro, 2011a). In fact, the Commission produced and sent to the Constitutional Assembly, through some of its members, a proposal for six articles to be included in the Constitution. Despite these efforts, in the session that took place on 20 August 1975, during which Fundamental Rights and Duties were discussed (Article 13), only the principle of the equality of all citizens before the law was accepted and the specific proposal for equal rights and duties for women was rejected since it was considered "discriminatory, given the general principle". In Point 2 (Art. 13), gender was included within other reasons for discrimination "against citizens" such as race, language and education, that were now banned (Monteiro, 2011a). The Constitutional Assembly proved to be a closed political opportunity structure, dominated by political party debates and the agenda for democratization. We should remember that in Brazil women parliamentarians in the 1986 and 1988 National Constitutional Assembly, were included irrespective of the political party to which they were affiliated, in what became known as the Lipstick Lobby, to demand the integration of a women's rights agenda, as stated by Rangel (2012). In Portugal, the universality and equality of rights was superimposed over the specific issue of women's rights, and this was clearly illustrated by the amused reactions to the Communist Party proposal to add an article entitled "Equal Rights for Women" (Ferreira, 2011; Monteiro, 2011a).

The Revolution represented the end of an authoritarian, conservative and antifeminist regime that had promoted conservative and welfare-based women's organizations (Pimentel, 2001), banned feminist associations, closed down the 
National Council of Portuguese Women (in 1948) and even in its so-called "spring" of 1972 seized a book and made its authors stand trial ${ }^{9}$. This is the opposite of what happened in Brazil during the dictatorship where women's movements, NGOs and advocacy networks could organize autonomously and then play an important role in the period of Constitutional Reform (Avelar, 2013). In Portugal, the feminist movements that emerged in the post-25 April 1974 period concentrated essentially on the campaign to decriminalize abortion. However, this period was undeniably marked by the violent reaction to a demonstration organized by the Women's Liberation Movement (in Portuguese, Movimento de Libertação das Mulheres) (MLM), in January 1975 in Lisbon:

It was a rally we wanted to hold in Parque Eduardo VII Park to burn various symbols associated with women, but not bras! None of us even wore them in those days! Women went dressed up as a vamp, a bride and a cleaner and we were going to burn the orange blossom and the duster. It had nothing to do with bras, that was completely made up! Helena Vaz da Silva wrote on the front page of the Expresso, and afterwards apologized for it, that we were going to do a striptease and so all these 'worms of men' turned up! And on top of that, idiots with placards that said "Pro-Life! Against Abortion!" Well, they got it too ... It was really rough. They groped us, hit us, tried to rape the women ... wrecked everything! The only woman left untouched was the bride. ... It was a disgrace ... The parties didn't support us, they made their excuses along with the rest. The media was a disgrace too. They made a lot of fun of the feminists (Maria Teresa Horta, interview, in http://www. cadernosdejornalismo.uc.pt/00/14-18.pdf; our translation)

This episode will suffice to understand the (lack of) space for women's movements in the revolutionary brew; all movements were accepted except women's movements. In particular it highlighted the view of feminist action from within the heart of the revolutionary process itself as a radical excrescence. The support given by the then Commission for the Feminine Condition to this movement and to these feminists was an important factor in legitimising its work. It was also a sign of the closeness between radical feminists and liberals in Portugal (Pena, 2008). However, before examining the welcome provided by the Portuguese gender equality mechanism in greater detail, we intend to focus on the reasons identified for this marginalization of the feminist movement in the post-revolutionary period.

Among the most frequently encountered explanations, and in addition to the machismo or misogyny that characterizes Portuguese society, emphasis should be given to the fact that intense party political struggle and dispute prevailed over all other agendas during this period of great political instability (Ferreira, 2011). Reactions to "feminism", embodied in the collective political imagination of the time
9. We mean Novas Cartas Portuguesas. The title of the English edition is The Three Marias, since it is authored by Maria Isabel Barreno, Maria Teresa Horta and Maria Velho da Costa. 
by the events surrounding the "Three Marias" and Women's Liberation Movement (MLM) episodes, were paradoxical, with opposition coming from traditionalists but also from the leading left-wing parties, who insulted women by calling them separatists, abortionists and reactionary bourgeoises (Barbosa, 1998) since, in their view, the only true battleground was the revolution and the class struggle (Ferreira, 1998; 2011; Tavares, 2011). In the period between the military coup of 1974 (noted above as the 'Carnation Revolution') and 1982, the political parties occupied the entire public sphere for mobilization. Centrists and elitists, they concentrated more on the power struggle and on ensuring conditions for "governability" in the face of the threat represented by the Communist Party more than on a pluralist form of politics open to projects and new social actors (Jalali, 2007). Avelar (2007) also believes that the reduced descriptive representation of women in Brazilian political parties is due to the choice made by these political structures to work to reinforce their male leaders' centralist power, instead of adopting a strategy of extensive inclusion such as that of social movements.

As in Spain (Valiente, 2007), religious conservatism and anti-feminism also appear to have been carried over as the institutional and social legacy of the Estado Novo era ("New State" dictatorship), determining rejection of emancipatory frames for women. This legacy was perpetuated in the shaping of the country's political-social system and in legal texts such as those concerning the family (Portugal, 2000), and was also evident in the erratic attitudes of the various political parties with regard to agendas for the sexual and reproductive rights of women (Monteiro, 2011a), for example.

It was difficult to achieve descriptive and substantive participation for women within the left-wing parties themselves and this is evident, for example, in the position of the Women's Democratic Movement (Movimento Democrático de Mulheres) (MDM) (controlled by the Communist Party) regarding an issue viewed as being too controversial and that did "not help liberate the country", in the words of one of the organization's leaders (Ferreira, 2011).

Confronted by all these hurdles, during this period of fragmentation, geographic centralism, weak social roots and elitism began to emerge as the features of Portuguese women's movements, due to the combined circumstances of the broader social and political context, as seen in the words of an MLM leader, later a femocrat:

[...] there was a feminist movement in Portugal...; it was different from the movements in other countries, it was concentrated in Lisbon and was very heterogeneous. It did not develop any collective consciousness or define common objectives. It was really a Statement of the everyday oppression of women (Barbosa, 1998:39, our translation). 
Other causes included the backwardness of the social sciences, the conservatism of universities, the lack of campaigning works apart from Novas Cartas Portuguesas, and the lack of sociological studies on the situation of women, which combined to block any critical debate on feminism (Amâncio, 1998; Ferreira, 1998). Even now insufficient theory and lack of debate are cited as negative features in the work of Portuguese women's movements.

All these forms of resistance, obstacles, non-receptiveness and inadequacies would have justified an early move by Portuguese women's movements towards the State or, more concretely, towards a State arena that welcomed them and gave them a common platform - the Non-Governmental Organizations Section of the Advisory Council (AC) of the Commission. This move began early in 1974, motivated by the need to prepare for the dynamics of International Women's Year (AIM) and its Conference in Mexico (Monteiro, 2010). It was a representative of one of the women's movements (the MDM) who knocked on the Commission's door to say that they wanted to collaborate and be included in the work. The Commission staff opened doors for them and decided to carry out the aforementioned survey with the aim of bringing the existing women's groups together (12 to be exact), including those linked to other political parties. The joint work was motivating and profitable. A Common Plan was produced for the Mexico Conference and for work on International Women's Year (1975), which would be the first body of work and political proposal produced jointly by the movements and the Commission. They represented Portuguese women at the first World Conference, constituting a sui generis delegation given that it was the only one that included NGOs. This cooperative work was to define the future relation between the women's movements, the official gender equality mechanism and the State for more than thirty years. The work was informal but well-articulated and intensive, and materialised in the creation of the NGO Section of the Commission Advisory Council (AC). It was the first time that the Commission had served as a means of access to the State and therefore as an ally of women's movements. As one femocrat told us in an interview...

The Mexico Conference gave us strength and courage to work here in this country. From then on nothing was the same. We brought ideas, information, arguments, and examples. To prepare it, we worked with the NGOs, we took them with us to the Conference, which was extremely pioneering! (int. 17, Commission official; our trans/ation).

How should this alliance with the State or this political institutionalization of Portuguese women's movements in the 1970s be interpreted?

We start from the premise that there was, in fact, a process of political institutionalization (Walker, 2005), in the sense that the movements were involved 
10. Associação Portuguesa de Estudos sobre as Mulheres (1991); Intervenção Feminina (1986); Aliança para a Democracia Paritária (1992); Rede de Mulheres Autarcas (1993). early on in cooperative relations with the State, their activists were simultaneously members of State institutions that were part of the State elites (senior officials and members of governments, for example). Some organizations were even founded within or on the basis of the initiatives of this State advisory mechanism ${ }^{10}$. We therefore reject simplistic and fatalistic interpretations that associate integration within the Advisory Council with a form of static institutionalization or cooptation. On the contrary, we consider that the political institutionalization of women's movements in Portugal has been a complex process whose evolution is the result of strategic options in the face of the political opportunities available, profoundly influenced by the context of the transition to democracy and the characteristics of Portuguese society. Thus the Advisory Council represented a niche for women's movements, provided by a State that was being modernized, occupied by elites with international connections who took on the role of entrepreneurs of norms and promoters of international models and which, moreover, offered a space for working and learning together. In addition to the political and governmental instability, the International Women's Year Conference and the International Year itself constituted focal events that created certain political opportunity structures during this period. Within the Commission, the context and actors therefore created input structures open to the women's movements, which saw in this institutional arena an opening or window of opportunity and pragmatically took advantage of it. The Commission was, therefore, an opportunities structure, a point of access or facilitator of access to political power, and the elites of the institution were allied to the women's groups, meaning that the attitude was therefore one of cooperating rather than contesting. In a context in which, as already noted, society, the political parties and the media itself were not receptive to feminist causes, the movements pragmatically viewed the State sectors in the process of modernization as potential allies.

However, this process can only be fully understood if we take into account the fact that certain internal features of movements also determine their choices including the profiles of their leaders (Banaszak, 1996; Morris \& Staggenborg, 2004). In the case of Portugal, we consider that the similarity between the profiles of the staff already in the Commission and that of the representatives of the women's groups facilitated this type of supportive relation, despite ideological diversity. In both cases it was not a matter of women working in the field, but rather of those who belonged to the central elites, the political parties, and the public administration and who also had, to a large extent, formerly belonged to the most progressive trends within the Catholic movements and been active in opposing the Estado Novo. It should also be emphasised that despite "working for the State", all the former Commission staff identified as feminists and profoundly militant when interviewed: 
It had the privilege of professionalizing militancy. The Commission was a "militant's den", an "erupting volcano". I felt that myself and my colleagues were feminists. It was a constant struggle, changing legislation after the Constitution. We were all working, even with the NGOs; there were no distinctions (int. 17, Commission official; our translation).

Taking a snapshot view of the Commission at the time, it is interesting to note how it reflected the contradictions that pervaded the Portuguese State, with its various layers, many making unlikely allies, ranging from the Catholic, albeit progressive, sectors to women from the far left, women from political parties from the entire political spectrum and from trade union confederations. What was the common denominator? They were all women from the elites or women who had special connections to the central elites (political parties, governments, the administration, the Roman Catholic Church). It was this shared sense of belonging in social terms and the shared biographies which would to some extent smooth over the ideological differences. In Brazil, as reported by Teixeira (2010), the route of femocratas was different, with closer links to social movements, as they stemmed from militancy against the dictatorship to feminist activism, and many of these women went on to universities, founded NGOs, held positions in government and public services.

In Portugal, other than its being the State's intention to co-opt women's organizations, it was the lack of political opportunity structures in other spheres, apart from the Commission, that lay behind this pragmatic and strategic option taken by women's associations, and which justified the creation of the NGO Section in the Commission's Advisory Council. The forging of a symbiotic relation between the Commission staff and the representatives of the women's associations in those early days of State feminism was a kind of "alliance of the marginalized" or "weakest links", a term used by Judith Squires (2007) in other contexts. For the Commission it represented a means of "listening to the voice of Portuguese women" and putting pressure on civil society to support women's demands and proposals, which was difficult for it to do in its own name, as a public body. For the women's associations, it was a possible forum which they could not find elsewhere in the political parties, the media, or society, and a comfortable structure for mobilization.

However, belonging to the Advisory Council affected the choice of repertoires for the movements' action and their mobilization structures (forming networks, recruiting members, strategies for strengthening or embedding them in society, types of activity, and funding sources). More specifically, the fact that this opening and institutional opportunity existed may have contributed towards attenuating other more campaigning and autonomous aspects, producing a certain acquiescence and dependence that depersonalised and disempowered both sides, as will be seen 
11. In 1979 the National Campaign for Abortion and Contraception (CNAC) was created, and later the Commission for the Legalisation of Abortion (1984), and the Oppinion Movement for the Decriminalisations of Abortion in Portugal (MODAP) (1990), for example (Tavares, 2011)

12. Until the 2000s the NGO Section of the Commission AC was responsible for coordinating the representation of Portuguese women's NGOs in the European Women's Lobby and the Association of Southern European Women. later. The Portuguese women's movements favoured this institutional platform to the detriment of other autonomous platforms outside the Commission that could have been tested.

This was the case during the abortion campaign ${ }^{11}$, which found no place on the institutional platform due to a lack of consensus between the NGOs and the deliberate distancing of the Commission from this doctrinal issue. Another important autonomous platform was created in 1987, under the influence of the European Women's Coordinator - the National Coordinator of Women's Organizations - which applied for a subsidy from the Commission for the Advisory Council members. Parliament approved this subsidy in 1989, with the right-wing parties voting against.

Warned of the risk of excessive centralization within the Advisory Council, the Chair of the Commission recommended in 1993 that the NGOs create an autonomous structure (Monteiro, 2011a). The NGOs believed it was impossible to remain actively militant in two structures and that this would create first and second class NGOs. In fact, ideological and party ruptures would hinder the cohesiveness of Portuguese women's NGOs and heighten rivalries, for example in terms of international representation ${ }^{12}$. It was only in 2004 that some associations founded the Portuguese Platform for Women's Rights which is now producing the Cedaw Shadow Reports and ensures representation in the European Women's Lobby (EWL). This platform does not, however, include some of the most active women's associations (Monteiro, 2011a).

\section{Ups and downs of State feminism}

Despite its lengthy and complex history, State feminism has had little effect in terms of achieving significant political results in Portugal. Our conclusion is that it was more important in terms of the networks created around it and the common biographies it contained. Since the phenomenon of State feminism emerged, the basis was formed for the relation between actors (the State, the political parties, women's associations and the Commission) to promote gender equality policies in Portugal. It was a relation in which the Commission was a fragile and marginalized, yet persistent and militant intermediary between the weak and dependent women's movements which it supported but did little to strengthen, and the centralizing, legalistic, clientist and conservative State which offered it few resources, little space and political relevance, but maintained it in response to the pressures of transnational feminism (Monteiro, 2011a).

The main gains of the Commission and its networks, namely the cases in which they managed to become insiders or, in other words, in which they were unable to become 
involved in the process of political decision-making (descriptive representation), but managed to ensure that legislative content essentially reflected their proposals (substantive representation), were concentrated in the last half of the 1970s. Examples of these hard-won achievements include the Review of the Civil Code and, specifically, of Family Law in 1977 (DL 496/77) (13 $^{13}$, the institutionalization of the Commission itself ( $D L 485 / 77$ ), the law on equal opportunities in the workplace and employment ( DL 392/79) and the Advertising Code (DL 421/80). These correspond to anti-discrimination policies whose underlying practice reflected the context of the modernization and democratization of the country.

From this point on action and achievements began to prove more difficult, and its role wavered between marginal and persistent but essentially formative intervention. We consider a marginal role as applying to situations in which the Commission sought to intervene and become involved in a particular agenda (in terms of internal discussion, reaching an understanding of the issue in question, drawing up proposals, etc.) but not succeeding in taking part in producing policies, as the system was closed to it (Monteiro, 2011a). This also reflects disrespect for its role as an advisory body, which includes the obligation to participate in all relevant legislation, in particular legislation emanating from the government. By a formative role we mean the agendas in which the Commission's work was more noticeable due to the persistent role it played in educating and raising awareness in society and the relevant political actors through language and reinterpretation (essentially by means of conferences, debates and publications), whose policy impact is deferred in time (Monteiro, 2011a). It resembles what Beckwith (2007) calls discursive politics, based on repeated exposure of the political situation of women and efforts to change institutions' political discourse.

This means that the Commission and its networks of organizations played a central role in policy proposals and their dissemination, launching agendas, producing knowledge and attempting to influence gender equality decision-making, but its actual capacity to influence was blocked and limited by exogenous factors, as political process and State feminism approaches suggest (McBride \& Mazur, 1995; 2008; 2010). It was marginal because it was excluded and discursive because it was disregarded by the political powers (Monteiro, 2011a). Within the range of factors that represent obstacles to the effectiveness of State feminism in Portugal, our study highlights the following:

a Certain characteristics of the legislative process, such as its centralism and non-receptiveness to outside groups (Cardoso, 2000; Ferreira, 1998; Mozzicafredo, 1997; Nicholls, 2007; Santos, 1993). This non-receptiveness translated, for example, into a disregard for the
13. Cf. <http://www. dgpj.mj.pt/DGPJ/sections/leis-da-justica/ pdf-leis2/dl-4961977/downloadFile/ file/DL_496_1977. pdf?nocache $=118$ 2361322.47>. 
14. In the interviews, this lack of prestige was exemplified in terms of the constant difficulties in "recruiting" female MPs, not to mention male MPs, to the parliamentary commissions on gender equality, due to a sense of embarrassment, loss of credibility and fear of adverse reactions (Monteiro, 2011a). advisory role of the Commission. As a consequence, this was reduced to its involvement in the production of legislation on the specific issue of gender equality between 1970 and 2007 - only $53 \%$ of the total legal provisions (Monteiro, 2011a).

- The lack of recognition of gender inequalities, the significance of social norms that were far removed from the egalitarian spirit of the law, and the concomitant limited political importance and prestige attributed to this area ${ }^{14}$ (Braithwaite, 2005; Monteiro \& Ferreira, 2009; Nogueira, 2009; Rêgo, 2010). The fact, already discussed, that the media had not been the best of allies for women and their representatives and was difficult to mobilize, certainly contributed towards this (Silveirinha, 2004).

- The fact that legal formalism was not accompanied by significant effectiveness, and that existing State and government departments did not implement the legislation, thus marginalizing equality issues. This reinforces the perception of the inability of the State, as a feature of the Portuguese political and administrative system (Cardoso, 2000; SANTOS, 1993). The inefficiencies systematically detected in the implementation of the Ist, 2 nd and 3rd National Plans for Equality are a perfect illustration of this (Cardoso, 2000; Ferreira et alii, 2007a, 2011). Among other factors, the lack of accountability in departments and the paralysis and rigidity of bureaucracy have blocked the "gender equality mainstreaming" strategy (Romão, 2006).

- The resistance, inconsistency and non-receptiveness of the parties to gender equality issues, which created relatively closed input structures for State feminism. In discussions on political parity, for example, ongoing over two decades, the Commission and its networks were only called upon to participate in 1997-98, despite the fact that this was the agenda that was the most consensual and important within State feminism in Portugal (Monteiro, 2011a; 2011b). The limited/ unsatisfactory $33 \%$ threshold of the so-called Parity Law (Law No. 3/2006), which states that "the lists for the Assembly of the Republic, the European Parliament and local authorities have to ensure a minimum representation of $33 \%$ of each sex", is an output of this closeness to women's representatives' demands (Monteiro, 2011b).

- The concomitant reduced importance and power of women's sections within the Portuguese parties (Jiménez, 2002; 2009) and, 
unlike the situation in Spain, the absence of "party feminism", meaning that the debate within the parties has been essentially male. In fact, only the Socialist Party (PS) has created and maintained a publicly visible formal women's section. However, unlike its counterpart in Spain, it has never been very strong and was instead maintained in response to the demands of the Socialist International. Comparison with Spain is interesting in this context since, although equally intense relations between women within the official mechanism and certain activists within the party existed, in Portugal these alliances were fragile or "weak links", whereas in Spain they involved powerful women who provided strong alliances and channels of influence to the heart of the Spanish Socialist Labour Party (Partido Socialista Obrero Español) (Arnedo, 2009; Threlfall, 2009; Valiente, 2005). The women in the Portuguese PS section seem to have occupied a decisive militant space within the Commission at the level of the Advisory Council and the NGOs created around $i^{15}$, as was the case of Maria Alzira Lemos and Ana Coucello, thus confirming that it is not the fact of belonging to a women's section that provides women with greater political clout within the Portuguese parties (Jiménez 2009), although it is generally cited as an advantage (Lovenduski, 1993). The chairs of the Parliamentary Commissions on Equality representing the Socialist Party were not leading figures within the party, and the same was true of the chairs of the women's sections.

a The impenetrability of the Assembly of the Republic with regard to the issue of gender inequality, which characterizes it as a closed political opportunity structure, since it is dominated by the parties and their priorities and offers formal working methods and procedures that are less receptive to outside groups. The Parliamentary Commissions dealing with gender equality ${ }^{16}$ and the development of networks involving women connected to the political parties were the means by which State feminism established points of access to this forum. These networks were used to present proposals such as the one for allocating subsidies to the Advisory Council NGOs (in 1989) or to press for the introduction of positive action policies. The difficulties in attracting MPs to these Commissions, the controversies surrounding re-nomination, and the systematic disrespect and disregard of which several former chairs have complained bear witness, however, to the weak influence of these organizations (Monteiro, 2011a).

u The resistance of Portuguese political actors to international norms,

\footnotetext{
15. Dedicated to the political parity agenda.

16. Subjected to various interruptions and demoted to subcommittees when there was a swing to a PSD majority parliament (in 1988 and 2002).
} 
particularly those which presuppose major reforms to systems, as was the case of positive action and mainstreaming mechanisms such as the Plans. Examples include the fact that the 1st Equality Plan only emerged in 1997, 9 years after it had been proposed by the Commission and women's organizations, gender budgeting was never implemented, despite being included in the $2 \mathrm{nd}$, in 2003, the issue of parity in politics was supported only by the Socialist Party and the Left Bloc (Bloco de Esquerda created in 1999), and the eponymous "Parity Law" was only approved in 2006.

- The fragility and lack of autonomy of Portuguese women's associations, which were unable to apply pressure to the political powers and the State (Amâncio, 1998; Ferreira, 1998; Tavares 2011). This fragility was frequently denounced with the phrase "they don't demand accountability, there's no pressure from the grassroots!", heard countless times in interviews. For example, in our analysis of the main joint actions of the NGOs in the AC, evidence emerged of the absence of this lobby, since during the lifetime of the Commission for the Feminine Condition only $42.5 \%$ of joint action consisted of presenting proposals for legislation or protests and institutional lobbying, and only $46.8 \%$ under the Commission for Equality and Women's Rights. This corresponds to 17 actions in 15 years of the Commission for the Feminine Condition, and 22 in 16 years of the Commission for Equality and Women's Rights (Monteiro, 2011a).

- The strength of conservative, familial legacies within and concerning Portuguese institutions (Portugal, 2000), which created obstacles to doctrinal agendas in particular such as abortion and sexual and reproductive health. In fact, the abortion agenda was a women's movement cause, although timidly and inconsistently supported by some parties on the left (Tavares, 2011) in opposition to the rightwing parties and the more conservative sectors of Portuguese society they represented. The Commission abandoned this agenda to the autonomous militancy of the movements, pleading its status as a

17. Not unconnected with the importance of women's associations in the Section linked to the church. public body and the lack of consensus among the NGOs on its Advisory Council ${ }^{17}$. With regard to the political parties, although it may be said that the main legislative initiatives concerning abortion, sex education and family planning came from left-wing parties, the fact was that even they feared confronting the most conservative sectors of Portuguese society and institutions up to the 2000s. After this point, which coincided with a more intense phase in the VIP agenda in Portugal 
(2001-2007), a clear differentiation could be seen between support from left-wing parties (Left Bloc, Socialist Party and Portuguese Communist Party) and opposition from the Social Democratic Party (PSD) and Social Democratic Center/Popular Party (CDS/PP). Prior to this, women in the female sections of the political parties denounced the contentions and even betrayals of political leaders regarding the issue of abortion (in the PCP, the issue was subordinated to the wider cause of the class struggle until the 1980s; in the PS, there was the agreement with the Social Democratic Party to hold a Referendum in 1998 and the subsequent victory of the No vote, due to a lack of support from the party leader, António Guterres).

Up to the 1990s, and given this marginalization within the State, the Commission developed a proactive attitude as a compensation strategy until it was transformed into the Commission for Equality and Women's Rights (1992), a milestone in attitude change. To complement this, it fostered networks and gathered together women from various backgrounds (the political parties, public administration, and associations) to create informal arenas within the party political system. These constellations, very flexible to contexts and political moments, facilitated access to political decision-making and enabled shared stories to be constructed, linked to the biographies of the Commission and women's organizations. However, due to their informal nature they ended up reproducing the marginality of women's and equality issues within the Portuguese political system and, as informal and horizontal mechanisms, were unable to leverage them into significant and visible levels of effectiveness. For this reason, we have termed them networks or "alliances of the marginalized", as Judith Squires describes them (2007).

There have been other, more successful moments for State feminism and gender equality policies in Portugal, such as the modernization of legislation in the post-revolutionary period, and also with changes brought about by center-left governments. In Portugal, political parties have made a certain difference, despite arguments concerning government indifference, in a system defined by alternating governments or the "majority shift" between the two majority center parties (Jalali, 2007). For this reason, the PS governments (I, XIII, XIV, and XVII governments) were considered by the interviewees to be their closest allies. As in Italy (Del Giorgio \& Lombardo, 2009) and Spain (Jiménez 2002, 2009), in Portugal more progress was made via the center-left than the center-right parties (Monteiro, 2011a). This confirms the argument found in literature that left-wing parties are facilitating structures and that changes towards governments of the left constitute moments in which political opportunity structures open up and are more favorable to women's movement campaigns and State feminism (Lovenduski, 2007). 


\section{Changes in State feminism and the current challenges facing women's movements}

The 1990s was the decade that marked the beginning of a change in State feminism, whose overall balance may be considered contradictory. On the one hand, with the swing in 1995 to a PS government and national echoes of more intense international pressure emerging out of the Beijing Platform for Action, there was greater visibility of and political attention to equality issues. On the other hand, there was a growing sense of political instrumentalization and changes in the profile of the Commission. It was ceasing to be the "militants' den" in the face of an uninterested State and beginning to become functionalized, gradually coming closer to a State bureaucracy and serving more as an executor than a proposer of policies. We interpret this scepticism within the broader context of a perception that denounces the institutionalization of notions of "gender" as an international general norm and policy (legitimized by the European Union, for example), to which very often only lip service is paid (FERreira, 2000; Squires, 2007).

In terms of the relation between the NGOs in the Advisory Council, signs emerged of the wearing down of the former synergetic relation, and of the NGO Section of the AC as a platform for the empowerment of women. In the 1990s, the relation changed from synergetic to fusional, revealing the excesses and limits of political institutionalization (Monteiro, 2011a). Several authors reported the growing institutionalization of movements in NGOs and its perverse effects, a process that was even designated as "ONGização" or "NGO boom" (NGO-isation) in the context of neoliberalization (Alvarez, 1999; 2008), denoting a certain "social movement crisis" in the 1990s, including in Brazil (Gohn, 2007).

In Portugal, women's associations, enclosed within a State structure as if it was their "home", almost forgot that they lived in civil society. Internal and external factors intensified from this point on to accentuate this exhaustion. On an internal level it involved:

1. An increase in the number and heterogeneity of the associations that made up the NGO Section of the Advisory Council (over 50), and the consequent loss of individual character;

2. The intensification of splits and conflicts, heavily marked by party political divisions and competition for funding;

3. The recognition of the limits for contesting within this platform, evident in the case of the decriminalising of abortion; 
4. Interventions by the supervisory body to create self-government and greater State regulation of the Section;

5. Modifications to the nature of the relation, which became guided by contracts and partnerships, and to forms of funding, making them project-based.

From 2002 onwards, with increasingly neoliberal tendencies defining the dynamics of governance and State management and meta-governance by the State (which brought new forms of funding and partnerships), the gradual distancing of women's movements from the State/Commission grew visibly. We classify this new relation as one of imposed and partnership-based autonomy (Monteiro, 2011a).

Using the arguments of efficiency and rationalisation in managing relations with civil society, accountability, partnership, stemming from the new logic for State management and governance, the Commission's supervisory bodies imposed a more formal and bureaucratic regulation on the NGO Section. The Commission produced new Section Regulations, new criteria for recognition of NGOs, and abolished the Management Committee and an office it had created. In 2005, the Chair of the Commission took back use of that room formerly given on Commission premises, making a symbolic and physical break with the close collaboration of the past.

Major technocratic adjustments also occurred in funding and support given by the State via the Commission, with the introduction of project-based and shortterm funding, a trend also highlighted in literature on the subject (OUTSHOORN \& KANTOLA, 2007). From 2002 onwards, State budget funds for subsidising NGOs were drastically cut $^{18}$, and support was channelled to programmes funded by the European Union (namely, the European Social Fund) ${ }^{19}$ for which women's organizations had to compete by presenting projects. These changes were strongly contested by the women's NGOs. The State then demanded:

1. Adjusting to the priorities and scripts which it defined (with projects competing in terms of priorities defined by the State);

2. Contracting for the provision of specialized services, such as those concerned with domestic violence, developed more from the perspective of certain women's associations which managed Statefunded shelters;

3. Territorialization of work and less elitism;

4. Accountability and enormous administrative and bureaucratic workloads;

18. In 2002 the funds allocated by the State budget to the NGO Section of the $\mathrm{AC}$ were cut by approximately $80 \%$.

19. Financial and Technical Support System to NGO's (SATF-ONG), in 2003; Axis 7 of the Human Potential Operational Programme (POPH), in 2008. 
20. Some NGOs expressed the opinion that the State was expecting them to provide underfunded services and work, relying on the expertise and goodwill of association leaders.
5. Competition with other NGOs, such as local development associations and charity institutions (under Satfong only $29 \%$ of the organizations funded were women's organizations);

6. Legitimation and prioritization of State policies. This project-based approach to support led to criticism from women's organizations who complained of a lack of support in comparison with other sectors of civil society (Ferreira, 2007b; PPDM, 2008) and even of the instrumentalization of the support ${ }^{20}$.

In general, the State withdrew the exclusive partnership for promoting gender equality and in doing so disqualified the organizations as favored interlocutors. As a result of the restructuring of the Commission in 2007, changes to the model whereby the AC functioned placed these symptoms under greater stress. In terms of its composition and from the perspective of intersectionality, it was now open to represent other forms of inequality (such as LGBT, religion, migration and disability), which created controversy around the idea of an "Olympics of the oppressed" in which groups competed for the title of "the most discriminated against" in order to gain attention and political support (Kantola \& Nousiainen, 2009). Contention also focused on the distancing of associations that had always been represented as the women's sections of political parties and trade unions. In terms of the operational model, these changes have also led to the perception that it is now an arena less dedicated to fostering discussion and participation and more of a politically legitimized advisory structure. Paradoxically, within the context of support for gender mainstreaming policies, the perception is that communication is completely unilateral and top-down. It is criticized for its inability to intervene directly in political matters, which are now debated top-down with much greater mediation and control on the part of the political hierarchies. The way in which the Equality Plans (I, II and III) were produced illustrates this process, with the supervisory body, despite requesting proposals from some of the Commission and even NGO staff, drawing up the measures itself in accordance with its political objectives, thus making the initial proposals unrecognisable or negligible (Monteiro, 2011a).

\section{Final remarks}

These features, which nowadays characterize the relation between women's movements and the State, reveal one of the main weaknesses/inconsistencies of gender mainstreaming policies in Portugal. Gender mainstreaming implies new concepts of democracy and governance, with the adoption of a bottom-up logic, monitoring and evaluating practices, financial accountability and transparency, which require, as Outshoorn \& Kantola emphasis (2007), strong women's movements (able 
to demand accountability and gender mainstreaming). Transversalisation forces the central State to rethink its centrality and (in)dependence in relation to other actors (namely those from civil society) and other levels of governance (such as the international agencies to whom it is accountable, the local levels with which it has to work, and the bureaucracies and mechanisms it has to maintain to coordinate the process).

In the name of more effective policies and less of the aforementioned discrepancy between the law and reality, the State-Commission-women's movement triad faces major challenges in Portugal. While the State is confronted with its persistent inability to implement gender equality policies, the present situation of the Portuguese women's movements is that of redefining and adjusting to a new profile. The major challenge is reinvention and resignification within a very difficult external environment. The challenge appears to be to create a new type of relation, between a past based on an exclusive relation with the Commission and informal alliances and collaboration within "marginalization", to a present in which the Commission and the sphere of equality policies are opening up to represent other groups and inequalities.

This redefinition of the role of women's associations is currently taking place at several levels:

- Redefining the relation with the Commission, which is no longer an arena for meeting and collaborative work but has become a partner with which they may work and which may finance their projects, but to whom they must also be accountable;

a Redefining their role in State equality policies, between the reduced opportunities for participation in drawing up government policies, and the growing call for participation in the execution, implementation and monitoring of already defined programmes and policies (see the example of their involvement in the Working Parties formed to monitor the National Plans for Equality).

- Redefining their status as civil society organizations, essentially dedicated to advocacy, and the pressure to establish partnerships to produce activities and provide services to the community, such as services for the victims of violence against women or equality education and awareness training. This tension was portrayed in some interviews, as pressure from the State for the associations to formalize the provision of services transform them into charities or to make other adjustments. Some have resisted this for fear of bureaucracy and increased financial responsibilities for human resources and facilities. 
21. Some Masters and $\mathrm{PhD}$ programmes for women's studies and feminist studies in some universities have brought several generations of women together to produce knowledge and form essentially informal and flexible militant feminist networks which are expanding, albeit loosely and without becoming heavily politicized.
- Redefining their militant arenas and repertoires, due to the exhaustion of the institutional arena of the NGO Section of the Advisory Council and the search for new arenas, new connections and integration within autonomous platforms.

Awareness of the exhaustion of the AC as an arena for political empowerment has led some organizations to seek out different and differentiated mobilization structures according to their interests, affinities and ideological lines in the search for new repertoires for action, which, having had autonomy imposed on them by the State, appears to be a positive movement. In the interviews, some representatives cited the importance of their links with NGOs, transnational feminist networks and other global social movements such as the World Social Forum and the Brazilian World March of Women, in the case of the Women's Union - Alternative and Answer (in Portuguese, União das Mulheres - Alternativa e Resposta) (Umar) (Tavares, 2011), and also with experts and university researchers ${ }^{21}$ and other women, constituting new cooperative constellations outside and beyond the staff of the Commission. Proabortion militancy, both in 1998 and especially in 2007, also led to a reinforcement of these new cooperative constellations, greater closeness and links with other groups and, in particular, new generations of feminists and certain associations. Experimentation with new feminist connections and militancy may be beneficial to women's associations and extend the tradition of "cooperation", now without an institutional remit. There is a growing awareness that the Commission Advisory Council and State support can no longer serve as the driving force behind forming women's associations, which must re-establish themselves and review their main strategies in terms of the concrete structures they face. The challenge will lie in how the new partnerships will cooperate and engage in conflicting situations.

We may conclude by stating that both the State and the women's movements find themselves today at a crossroads that offers multiple challenges. In this time of all dangers, due to the grave economic crisis that erupted in 2008, gender mainstreaming of policies is completely off the agenda of political debate in Portugal. The restructuring of markets and of politics will certainly have an impact on the way we define citizenship rights, namely women's rights. In fact, a different way of connecting markets, politics and rights seems to be emerging, which will change the State of affairs for implementing gender equality policies and for mobilizing social movements. 
Resumo: Este artigo pretende contribuir para uma melhor compreensão das dinâmicas dos movimentos de mulheres e de suas relações com as instituições, partidos políticos e mecanismos oficiais que promovem a igualdade de gênero. Resulta do primeiro estudo acerca do feminismo de Estado em Portugal. A pesquisa assentou num estudo de caso centrado no principal mecanismo oficial para a igualdade e as suas redes, com a mobilização de uma abordagem qualitativa. Concluímos que, na atualidade, enquanto o Estado português está confrontado com a sua persistente incapacidade para implementar as políticas de igualdade de gênero, a situação presente dos movimentos de mulheres portugueses é de redefinição e acomodação aos principais desafios de reinvenção e ressignificação num contexto externo muito difícil.

Palavras-chave: movimentos de mulheres, Estado, feminismo de Estado, partidos políticos, Portugal.

\section{References}

ALVAREZ, Sónia E. Beyond the civil society agenda: "civic participation' and practices of governance, governability and governmentality". Presented at Centro de Estudos Sociais da Universidade de Coimbra, 1 july 2008.

- Advocating feminism: the Latin American Feminist NGO "Boom". International Feminist Journal of Politics, 1 (2), p. 181-209, 1999.

AMÂNCIO, Lígia. O feminismo português no final do séc. XX: um olhar sobre o passado ausente e a promessa do futuro. Paper presented at the conference Movimento Feminista em Portugal (Umar). Lisboa, 5-6 Dec. 1998.

ARNEDO, Elena. Mujer y socialismo. In: TEN, C. M.; LÓPEZ, P. G.; RUIZ, P. G. (Eds.). EI movimiento feminista en España en los años 70. Madrid: Cátedra, 2009.

AVELAR, Lúcia. Movimentos, redes, feminismo de Estado: a representação extraparlamentar das mulheres brasileiras. Cadernos Adenauer, XIV (3), p. 71-87, 2013.

BANASZAK, Lee Ann. Why movements succeed or fail: opportunity, culture, and the struggle for woman suffrage. New Jersey: Princeton University Press, 1996.

BARBOSA, Madalena. A criação de um mito. Paper presented at the conference Movimento Feminista em Portugal (Umar). Lisboa, 5-6 Dec. 1998.

BECKWITH, Karen. Mapping strategic engagements: women's movements and the State. International Feminist Journal of Politics, 9 (3), p. 312-338, 2007.

BRAITHWAITE, Mary. Gender - sensitive and women friendly public policies: a comparative analysis of their progress and impact. Final Report of Equapol project, 2005. <http://www.equapol.gr/pdf/HPSE-CT-2002-00136_DEL9_FinalReport.pdf>. Accessed in: 30 Nov. 2010. 
CARDOSO, João Casqueira. O projecto "prever o impacto das políticas": pressupostos e principais pontos". Exæquo, n. 2-3, p. 75-91, 2000.

CELIS, Karen. Gendering representation. In: GOERTZ, G.; MAZUR, A. G. (Eds.). Politics, gender, and concepts: theory and methodology. Cambridge: Cambridge University Press, 2008.

DEL GIORGIO, Elena; LOMBARDO, Emanuela. Institutionalising intersectionality in Italy: gatekeepers and political dynamics. Paper presented at the ECPR Joint sessions of workshop, 14-19 Apr. 2009.

FERREIRA, Virgínia. Engendering Portugal: social change, State politics and women's social mobilization. In: PINTO, A. C. (Ed.). Contemporary Portugal. 2. ed. Boulder: Social Science Monographs. New York: Columbia University Press, 2011.

—. A globalização das políticas de igualdade entre os sexos: do reformismo social ao reformismo estatal. Exæquo, n. 2-3, p. 13-42, 2000.

- Engendering Portugal: social change, State politics and women's mobilization; In: PINTO, A. C. (Ed.). Modern Portugal. Palo Alto (CA): Sposs - The Society for the Promotion of Science and Scholarship, 1998.

FERREIRA. Virgínia et alii. Estudo de avaliação do III Plano Nacional para a Igualdade - cidadania e género. Relatório Final para a CIG. Lisboa: CIG, 2011.

. Estudo de avaliação do II Plano Nacional para a Igualdade. Report to CIDM. Lisboa: CIG, 2007a.

. Estudo diagnóstico e prospectivo sobre o papel das ONG na promoção da igualdade de oportunidades entre mulheres e homens. Report to CIDM. Lisboa: CIG, 2007b.

FRANCESCHET, Susan. "State feminism" and women's movements: the impact of Chile's Servicio Nacional de Mujer on women's activism. Latin American Research Review, 38 (1), p. 9-40, 2003.

GOHN, Maria da Glória. Teorias dos movimentos sociais: paradigmas clássicos e contemporâneos. São Paulo: Loyola, 2007.

HTUN, Mala; WELDON, Laurel. When and why do governments promote women's rights? Toward a comparative politics of States and sex equality. Paper presented at the American Political Science Association Annual Meeting. Chicago, 2007.

JALALI, Carlos. Partidos e democracia em Portugal 1974-2005. Lisboa: ICS, 2007. 
JIMÉNEZ, Antonia M. Ruiz. Women and decision-making participation within rightist parties in Portugal and Spain. Análise Social, XLIV (191), p. 235-263, 2009.

- Mecanísmos del cambio ideológico e introducción de políticas de género en partidos conservadores: el caso de Ap-Pp en España en perspectiva comparada. Madrid: Instituto Juan March, 2002.

KANTOLA, Johanna; NOUSIAINEN, Kevät. Institutionalising intersectionality in Europe: legal and political analyses. Paper presented at the First European Conference on Politics and Gender. Belfast, 21-23 Jan. 2009.

LOVENDUSKI, Joni. State feminism and women's movements. West European Politics, 31 (1), p. 169-194, 2008.

LOVENDUSKI, Joni. Unfinished business: equality policy and the changing context of State feminism in Great Britain. In: OUTSHOORN, J.; KANTOLA, J. (Eds.). Changing State feminism. Basingstoke: Palgrave MacMillan, 2007.

- Introduction: the dynamics of gender and party. In: LOVENDUSKI, Joni; NORRIS, Pippa (Eds.). Gender and party politics. London: Sage, 1993.

MAZUR, Amy; MCBRIDE, Dorothy (Coord.). The politics of State feminism: innovation in comparative research. Philadelphia: Temple Univ. Press, 2010.

MAZUR, Amy. The impact of women's participation and leadership on policy outcomes: a focus on women's policy machineries. Expert Group Meeting on Equal participation of women and men in decision-making processes, with particular emphasis on political participation and leadership, 2005.

MCADAM, Doug. On the international origins of domestic political opportunities. In: COSTAIN, A. N.; MCFARLAND, A. S. (Eds.). Social movements and American political institutions. Lanham: Rowman \& Littlefield, 1998.

MCBRIDE, Dorothy M.; MAZUR, Amy G. Women's movements, feminism, and feminist movements. In: GOERTZ, G.; MAZUR, A. G. (Eds.). Politics, gender, and concepts: theory and methodology. Cambridge: Cambridge University Press, 2008.

MCBRIDE, Dorothy M.; MAZUR, Amy et alii. RNGS project description 5/05. 2005. <http://libarts.wsu.edu/polisci/rngs/pdf/project505.pdf>. Accessed in 20 Mar. 2007.

MCBRIDE, Dorothy M. (Ed.). Abortion politics, women's movements and the democratic State: a comparative study of State feminism. Oxford: Oxford University Press, 2001. 
MCBRIDE, Dorothy M.; MAZUR, Amy (Eds.). Comparative State feminism. Thousand Oaks: Sage, 1995.

MOLYNEUX, Maxine. Mobilization without emancipation? Women's interests, the State, and revolution in Nicaragua. In: MCCANN, C. R.; KIM, S.-K. (Eds.). Feminist theory reader: local and global perspectives. New York: Routledge, 2003.

MONTEIRO, Rosa. Feminismo de Estado em Portugal: mecanismos, estratégias, políticas e metamorfoses. Doctoral Thesis. Coimbra, FEUC/CES, University of Coimbra, 2011a.

A política de quotas em Portugal: o papel dos partidos políticos e do feminismo de Estado. Revista Crítica de Ciências Sociais, n. 92, p. 31-50, 2011b.

A emergência do feminismo de Estado em Portugal: uma história da criação da Comissão da Condição Feminina. Lisboa: CIG, 2010.

MONTEIRO, Rosa; FERREIRA, Virgínia. The political process of gender mainstreaming in Portugal: actors and instruments. Paper presented ECPR General Conference. Potsdam, 11-13 Sep. 2009.

MORRIS, Aldon D.; STAGGENBORG, Suzanne. Leadership in social movements. In: SNOW, D. A.; SOULE, S. A.; KRIESI, H. (Eds.). The blackwell companion to social movements. Malden: Blackwell, 2004.

MOZZICAFREDO, Juan. Estado providência e cidadania em Portugal. Oeiras: Celta, 1997.

NICHOLLS, Kate. Europeanizing responses to labour market challenges in Greece, Ireland and Portugal: the importance of consultative and incorporative policymaking. Doctoral thesis Graduate School of the University of Notre Dame. South Bend (IN), 2007.

NOGUEIRA, Conceição. Women in positions of power in Portugal: contradictory positions and discourses. Journal of Women, Politics \& Policy, 30 (1), p. 70-88, 2009.

OUTSHOORN, Joyce; KANTOLA, Johanna (Eds.). Changing State feminism. Basingstoke: Palgrave Macmillan, 2007.

PENA, Cristiana. A revolução das feministas portuguesas 1972-1975: do "processo das Três Marias" à formação do MLM - Movimento de Libertação das Mulheres. Master's dissertation, Universidade Aberta, 2008.

PIMENTEL, Irene Flunser. As organizações femininas do Estado Novo. Lisboa: Temas \& Debates, 2001. 
PORTUGAL, Sílvia. Retórica e acção governativa na área das políticas de família desde 1974. Revista Crítica de Ciências Sociais, n. 56, p. 81-98, 2000.

PLATAFORMA PORTUGUESA PARA OS DIREITOS DAS MULHERES (PPDM). Portugal Shadow Report, the 6th and 7th governmental periodic CEDAW reports, 2008.

RAY, Raka. Fields of protest: women's movements in India. New Deli: Zubaan Books, 2000.

RANGEL, Patrícia. Movimentos feministas e direitos políticos das mulheres. PhD Thesis, Instituto de Ciência Política, Universidade de Brasília, Brasília, 2012.

RÊGO, Mạ do Céu da C. A construção da igualdade de homens e mulheres no trabalho e no emprego na lei portuguesa. In: FERREIRA, V. (Ed.). A igualdade de mulheres e homens no trabalho e no emprego: políticas e circunstâncias. Lisboa: Cite, 2010.

ROMÃO, Isabel. Implementation of gender mainstreaming at governmental level in the EU member States. Lisboa: CIDM, 2006 (mimeo).

SANTOS, Boaventura de Sousa. A crítica da governação neoliberal: o Fórum Social Mundial como política e legalidade cosmopolita subalterna. Revista Crítica de Ciências Sociais, n. 72, p. 7-44, 2005.

—. O Estado, as relações salariais e o bem-estar social na semi-periferia: o caso português. In: SANTOS, Boaventura de Sousa (Org.). Portugal: um retrato singular. Oporto: Afrontamento, 1993.

SILVEIRINHA, Maria João. Identidades, media e política. O espaço convencional nas democracias liberais. Lisboa: Livros Horizonte, 2004.

SQUIRES, Judith. The new politics of gender equality. New York: Palgrave, 2007.

TARROW, Sidney. Power in movement: social movements and contentious politics. Cambridge: Cambridge University Press, 1998.

TAVARES, Manuela. Feminismos, percursos e desafios (1947-2007). Lisboa: Texto Editora, 2011.

TEIXEIRA, Simone Andrade. Matrizes e matizes das estratégias de inserção dos direitos sexuais e direitos reprodutivos engendrados por feministas acadêmicas. 2010. Available at <www.repositorio.ufba.br8080/ri/bitstream/ri/6304/1/Tese Final.pdf>. 
THRELFALL, Mónica. El poder transformador del movimiento de mujeres en la transición política española. In: TEN, Carmen M.; LÓPEZ, Purificación G.; RUIZ, Pilar G. (Eds.). El movimiento feminista en España en los años 70. Madrid: Cátedra, 2009.

VALIENTE, Célia. Are gender equality institutions the policy allies of the feminist movement? A contingent "yes" in the Spanish central State. South European Society and Politics, 12 (3), p. 315-334, 2007.

- The women's movement, gender equality agencies and central-State debates on political representation in Spain. In: LOVENDUSKI, J. (ed). State feminism and political representation. Cambridge: Cambridge University Press, 2005.

— . El feminismo de Estado en Portugal: la creación de la Comissão para a Igualdade e para os Direitos das Mulheres y su relación con el movimiento de mujeres. In: UMAR, Actas do Seminário: Movimento Feminista em Portugal, 1998. Available at: <http://umar.no.sapo.pt/investigacao/comunicacoes/Semin\%E1rio_ Mov.Feminista.pdf $>$.

WALBY, Sylvia. A União Europeia e as políticas de igualdade de oportunidades. Exæquo, n. 2-3, p. 53-74, 2000.

WALKER, Edward. The interpenetration of system and lifeworld: political, cultural, and organizational processes of social movement institutionalization. Paper presented at ASA Annual Conference. Montréal, 2005. 